\title{
EVALUASI PROGRAM PENGENTASAN KEMISKINAN DI KOTA YOGYAKARTA
}

\author{
Oleh: \\ Gunardo R.B. \\ Jurusan Pendidikan Geografi, FISE UNY
}

\begin{abstract}
Abstrak
Kajian evaluasi program pengentasan kemiskinan menunjukkan bahwa program-program pengentasan kemiskinan yang telah dilaksanakan meliputi: program Padat Karya dan Program Pengentasan Kemiskinan Perkotaan (P2KP) dari Dinas Permukiman dan Prasarana Wilayah, Kartu Sehat dari Dinas Kesehatan, Beras Miskin dari Pemerintah Kota, Pelatihan Ketrampllan dan Bantuan Modal Usaha dari Dinas Kesejahteraan Sosial, Kuliah Kerja Nyata dari berbagai perguruan tinggi, dan Beasiswa untuk anak-anak miskin dari Dinas Pendidikan.

Program-program pengentasan kemiskinan itu tidak semuanya berhasil, yang dianggiap berhasil oleh warga miskin yaitu program padat karya, P2KP, Kartu Sehat dan Beras Miskin. Adapun program-program pelatirian dianggap gagal. Keluarga miskin di Kota Yogyakarta sesungguhnya mempunyai motivasi yang cukup kuat untuk melepaskan diri dari predikat kemiskinannya. Aspirasi yang mereka sampaikan adalah agar melibatkan keluarga miskin dalam program-program pengentasan kemiskinan, terbentuknya paguyuban yang dapat menampung berbagai aspirasi, usul, saran dan kritik. Diharapkan ada tindak lanjut pelatihan dlikuti penampungan tenaga kerja atau pemasaran hasil produknya. Perlu juga penanganan kaum ulama sehingga motlvasi warga miskln tidak mudah patah dalam menghadapi tantangan yang berat ini dan untuk memperbaiki moral dan mental warga miskin.
\end{abstract}

Kata kunci: evaluasi, program, kemiskinan

Pendahuluan

Sejak tahun 2000 telah dicanangkan Tujuan Pembangunan Millenium atau Millenium Development Goals 2015. Dokumen ini telah 
|| Evaluasi Program Pengentasan Kemiskinan di Kota Yogyakarta

ditandatangani oleh 191 negara anggota Persatuan Bangsa-Bangsa termasuk Indonesia. Oleh karena itu pemahaman tentang MDGs ini perlu terus disampaikan kepada masyarakat agar tumbuh kesadaran bersama untuk berusaha mewujudkannya. Pada akhirnya masyarakat juga yang akan menikmati hasilnya apabila MDGs dapat terwujud.

Salah satu tujuan pembangunan milenium 2015 adalah berkurangnya jumlah penduduk mskin hingga separuhnya. Akan tetapi menurut Awan Setya Dewanta, dkk. (1995), data di lapangan menunjukkan bahwa jumlah penduduk miskin justru bertambah, padahal berbagai program pengentasan kemiskinan telah dilaksanakan oleh pemerintah. Tentu ada penyebab gagalnya program pengentasan kemiskinan tersebut. Oleh karena itu perlu pengkajian atau semacam evaluasi terhadap program pengentasan kemiskinan. Selama ini kegagalan program pengentúsan kemiskinan dilimpahkan seluruhnya kepada pemerintah. Bagaimana dengan suara atau aspirasi warga miskin sendiri belum banyal diketahui. Untuk itu ada baiknya suara atau aspirasi penduduk miskin terhadap program pengentasan kemiskinan perlu diserap dan dikaji untuk dijadikan pertimbangan pemerintah dalam menyusun perencanaan yang te.pat sehingga target MDGs 2015 dapat terwujud.

\section{Tujuan Pembangunan Milenium 2015}

Beberapa tujuan MDGs 2015, antara lain:

1. Menanggulangi kemiskinan dan kelaparan sampai setengahnya.

2. Mewujudkan pendidikan dasar untuk semua.

3. Mendorong kesetaraan gender dan memberdayakan perempuan.

4. Menurunkan angka kematian bayi dan balita sampai dua pertiganya.

5. Meningkatkan kesehatan ibu dengan menurunkan angka kematian ibu melahirkan sampai dua pertiga.

6. Memerangi penyebaran HIV/AIDS, malaria dan penyakit menular lainnya.

7. Menjamin kelestarian fungsi lingkungan hidup.

8. Mengembangkan kemitraan global untuk pembangunan.

\section{Kemiskinan Berbagai Versi}

Sehubungan dengan aneka ragamnya data kemiskinan yang beredar di masyarakat beberapa waktu yang lalu maka Walikota Yogyakarta menerbitkan Peraturan Walikota No. 39-2005 tanggal 14 April 
2005 tentang Parameter Kemiskinan Kota Yogyakarta. Hal itu dipandang perlu karena ketidaksamaan data yang dikeluarkan oleh berbagai instansi (Badan Pusat Statistik, Dinas Kesehatan, Dinas Sosial, BKKBN) menyebabkan tumpang tindihnya kebijaksanaan ditingkat basis (RT/RW). Oleh karena itu sesuai dengan kewenangannya maka Walikota menetapkan satu parameter kemiskinan untuk dijadikan tolok ukur bagi setiap instansi yang menangani kemiskinan. Secara koordinatif Walikota juga telah mengangkat sebuah Komite Penanggulangan Kemiskinan Kota untuk mengkoordinir upaya pemberantasan kemiskinan dengan SK Walikota Nomor 204/KEP/2005 tertanggal 29 Mei 2005.

Oleh karena pentingnya parameter kemiskinan itu maka masyarakat luas perlu mengetahuinya secara detail. Bagi yang miskin dapat mengetahui dirinya termasuk dalam kategori miskin atau tidak sehingga tidak salah bila mengajukan bantuan kepada pemerintah, sedangkan bagi yang tidak miskin apalagi mempunyai hart'd berkelebihan dapat ikut berpartisipasi dalam pemberantasan kemiskinan. Di bawah ini diuraikan secara populer tentang parameter kemiskinan, yaitu:

1. Sebuah keluarga yang tidak bisa makan 2 kali sehari tergolong sebagai keluarga miskin. Tidak dijelaskan kualitas makanan yang dikonsumsi keluarga tersebut sebab bisa saja makan 2 kali sehari kualitasnya lebih tinggi daripada makan 3 kali sehari. Kriteria ini lebih mengacu pada pengakuan keluarga tersebut saja.

2. Keluarga yang tidak dapat makan daging/ikan/tahu dalam satu minggu digolongkan keluarga miskin. Padahal diketahui bahwa tahu/tempe merupakan makanan sehari-hari warga Kota Yogyakarta. Dengan demikian berdasarkan kriteria ini tidak sebuah pun keluarga di Kota Yogyakarta tergolong miskin.

3. Keluarga yang mengkonsumsi kurang dari 2100 kalori/orang/hari digolongkan keluarga miskin. Hal ini tentu menyulitkan untuk menggolongkan sebuah keluarga termasuk miskin atau tidak karena perlu alat ukur untuk menghitung jumlah kalori sebesar 2100. Akan lebih mudah seandainya hitungan kalori diekuivalenkan dengan kilogram beras sehingga masyarakat mudah memahaminya.

4. Bagi mereka yang tidak memiliki pakaian berbeda, maksudnya pakaian untuk dirumah, pakaian untuk bepergian, dan pakaian untuk bekerja semuanya sama, maka keluarga tersebut termasuk miskin. Misalnya: Seseorang di rumah menggunakan pakaian yang sama untuk 
berdagang dan untuk kondangan berarti hanya punya 1 stel saja. Kiranya hanya sedikit saja keluarga yang memenuhi syarat kecuali kalau pengakuan saja dapat dijadikan alasan untuk dapat dimasukkan dalam kategori miskin.

5. Keluarga yang tidak dapat membeli pakaian baru dalam setahun maka digolongkan keluarga miskin. Persoalannya ini juga hanya pengakuan saja, jadi sulit untuk mengontrolnya.

6. Apabila lantai rumahnya itu sebagian besar masih berupa tanah maka digolongkan miskin. Keadaan ini mudah diamati dan obyektif, apalagi dihubungkan dengan kriteria ke 7.

7. Luas lantai $8 \mathrm{~m}^{2}$ /orang, artinya kalau keluarga beranak 1 yang tinggal di rumah tipe 21 tergolong miskin karena luas lantainya minimal $3 \times 8$ $\mathrm{m}^{2}=24 \mathrm{~m}^{2}$. Seharusnya pembangunan tipe 21 ditiadakan saja.

8. Kalau rumahnya tidak ada dinding penyekat (blak-blakan), artinya orang bisa melihat tempat tidur, meja tamu, dapur, maka keluarga itu masuk kategori miskin.

9. Bila penghasilan keluarga yang digunakan untuk konsumsi makanan sama dengan untuk pengeluaran non makanan (pendidikan, kesehatan, permukiman dan sosial) maka tergolong miskin.

Misalnya: Gaji seseorang Rp 300.000,-; untuk makan Rp 150.000,-; untuk kontrak rumah, sumbangan sosial, bayar sekolah, dan lain-lain Rp 150.000,-. Praktis tidak akan dapat menabung maka miskinlah keluarga itu. Kriteria ini juga hanya pengakuan saja.

10. Kriteria yang dapat diukur adalah penghasilan keluarga itu setara dengan $360 \mathrm{~kg}$ beras/tahun/orang. Kalau harga beras Rp 3.000,-/ kg maka penghasilan minimal $360 \times \mathrm{Rp} 3.000,-=\mathrm{Rp} 1.080 .000,-/$ tahun atau Rp 90.000/orang/bulan. Jadi bila keluarga itu anaknya 3 orang maka penghasilan minimalnya $=5 \times \mathrm{Rp} 90.000,-=\mathrm{Rp} 450.000,-$ untuk tidak digolongkan miskin.

11. Kriteria lainnya adalah bila keluarga itu tidak mampu ke Puskesmas. Dengan retribusi Rp 600,- tentu semua warga mampu menjangkaunya. Masalahnya justru biaya transport ke Puskesmas jauh lebih besar dari retribusinya. Ada kalanya jarak ke Puskesmas dengan tempat tinggal relatif jauh, sehingga perlu naik becak pulang pergi minimal Rp 5.000,-. Oleh karena itu kriteria ini perlu dikoreksi. 
12. Warga yang tidak mempunyai fasilitas Mandi Cuci Kakus (MCK) sendiri digolongkan miskin, artinya mereka yang menggunakan fasilitas MCK umum masuk kategori ini.

13. Keluarga yang mempunyai balita gizi buruk digolongkan keluarga miskin. Kriteria ini agak susah karena bisa terjadi anaknya Kepala Dinas ternyata bergizi buruk bukan karena tidak punya uang, tetapi makariannya disantap baby sitter yang malas menyuapi. Gizi buruk juga lebih nampak dari tanda-tanda luar balita tersebut, misalnya kulit keriput dan berat badan rendah.

14. Bila ada ibu hamil kekurangan energi protein, maka keluarga itu tergolong miskin. Seharusnya lebih diperjelas kriteria energi protein itu apa dan berapa, jadi ada ukuran yang dapat diamati tiap orang.

15. Kriteria berikut adalah bila di keluarga itu ada anak yang drop out dari wajib belajar 9 tahun. Kiranya syarat ini sudah sangat jarang di Kota Yogyakarta di tengah gencarnya Walikota memberikan beasiswa.

16. Keluarga yang tidak mempunyai keterampilan (menjahit, memasak, berdagang) untuk bekal bekerja tentu tidak akan mempunyai peng,hasilan sehingga tergolong miskin. Adapun sumber pendapatannya dari sumbangan orang tua atau saudara. Pola ini masih banyak terjadi di Kota Yogyakarta karena faktor budaya misalnya peribahasa "Mangan ora Mangan angger kumpul. Sehingga orang tua rela memberi makanan anak cucu supaya tidak berpisah atau merasa ditinggalkan. Jadilah reluarga itu tidak berpenghasilan tetap tetapi makan setiap hari.

17. Kalau di rumah tidak ada radio, televisi atau tidak berlangganan surat kabar maka keluarga ini termasuk miskin. Kiranya sangat jarang di kota orang tidak mempunyai televisi. Karena benda yang satu ini sekarang harganya relatif murah dan mudah didapat.

18. Bila sebuah keluarga tidak terlibat kegiatan sosial kemasyarakatan Misalnya: tidak pernah ikut ronda, tidak pernah ikut rapat warga di RT/PKk, tidak pernah mengikuti pengajian, tidak mau kerja bakti, tidak pernah melayat, maka keluarga ini benar-benar tergolong miskin terutama miskin sosial. Sebenarnya keluarga yang sibuk mencari penghasilan untuk menghidupi keluarganya bisa jadi tidak mengikuti kegiatan sosial kemasyarakatan, sama dengan orang kaya yang dapat membayar ronda, kerja bakti dan lain-lain dengan uangnya tanpa pernah hadir secara fisik. Memang agak sulit menentukan kriteria ini kalau hanya pengakuan saja. 
19. Orang yang sudah menerima bantuan sosial misalnya mendapat beras miskin, memperoleh kartu sehat, menerima pakaian bekas dan menerima zakat maka digolongkan orang miskin meskipun karena salah kriteria atau kesengajaan, berhubung yang bersangkutan kerabat dekat pemegang keputusan.

20. Kriteria yang ini tidak jelas yaitu mempunyai peralatan rumah tangga seadanya. Keluarga yang tidak mempunyai tempat tidur, meja tamu, almari pakaian, peralatan dapur tergolong miskin. Tidak jelasnya karena peralatan rumah tangga itu relatif dari segi macam, kualitas dan harga, jadi memerlukan interpretasi yang lebih obyektif.

21. Sebagai kriteria terakhir adalah penggunaan penerangan listrik. Bila masih menumpang orang lain atau bahkan tidak menggunakan listrik maka otomatis tergolong miskin. (Kompas, 17 Desember 2005).

Kalau diamati maka ada beberapa kriteria yang hanya berdasarkan pengakuan saja (nomor 1, 2, 3, 4, 5, 9, 14, dan 18), sehingga tidak ada kontrol dan akibatnya di lapangan sering bentrok antara petugas dengan keluarga yang didata. Ada juga kriteria yang sulit diukur (nomor 13, 16, 19 dan 20) sehingga berpotensi menimbulkan salah interpretasi, dan pada akhirnya menimbulkan konflik vertikal maupun horizonial. Untuk itu sebaiknya peraturan perlu ditinjau ulang, agar lebih jelas k.riterianya, gampang dimengerti dan ada tolok ukurnya.

Parameter yang disempurnakan ke depan memudahkan penanggulangan kemiskinan di Kota Yogyakarta. Berbagai pihak perlu dilibatkan, termasuk mereka yang tergoiong miskin. Selama ini mereka hanya menjadi obyek. Sudah saatnya mereka diajak berpartisipasi, didengarkan sehingga diketahui apa saja keinginan dan harapan kieluarga miskin.

Sebagai perbandingan disampaikan kriteria Grameen Bank yang menentukan seorang anggota dinilai telah keluar dari garis kemiskinan jika memenuhi kriteria berikut ini:

1. Keluarga mereka hidup di rumah seharga minimal 25.000 taka (sekitar Rp. 4,5 juta) atau rumah dengan atap seng, dan setiap anggota bisa tidur di kasur, bukan di lantai.

2. Mereka minum air bersih dari sumur, air masak atau air yang disuling.

3. Anak-anak berusia di atas enam tahun sudah masuk sekolah c.tau menyelesaikan SD.

4. Pinjaman minimum mingguan adalah 200 taka (sekitar Rp. 36.000,-). 
5. Keluarga itu memiliki kakus yang layak.

6. Anggota keluarga memiliki jumlah pakaian yang memadai untuk penggunaan sehari-hari, baju hangat untuk musim dingin, dan kelambu untuk melindungi diri mereka dari nyamuk.

7. Memiliki sumber-sumber penghasilan tambahan, misalnya dari kebun sayur atau pohon buah, yang bisa mereka gunakan jika mereka meinbutuhkan tambahan uang.

8. Peminjam harus memiliki tabungan pribadi sedikitnya 5.000 taka (Rp. 900.000)

9. Keluarga peminjam tak kesulitan mengkonsumsi makanan tiga kali sehari sepanjang tahun. Tak ada satupun anggota keluarga yang kelaparan selama periode itu.

10. Keluarga peminjam bisa mengurusi problem kesehatan mereka. Jika ada salah satu anggota keluarga yang sakit, mereka mampu mengambil tindakan yang diperlukan di bidang kesehatan. (Majalah Tempo, 19 November 2006 hal 690).

\section{Evaluasi Program Pengentasan Kemiskinan}

Hasil penelitian yang dilaksanakan Gunardo R.B. (2007) di Kelurahan Kricak Kecamatan Tegalrejo Kota Yogyakarta menunjukkan bahwa program pengentasan kemiskinan yang dinilai paling berhasil adalah model Padat Karya, karena warga merasa mendapat bantuan tetapi mereka juga merasa berjasa yaitu bekerja. Ada perasaan bangga ketika mereka menerima upah dari hasil keringatnya. Kerjanya tidak begitu berat dan hanya diawasi oleh seorang pemimpin kelompok yang kebetulan menjabat sekretaris RTnya sendiri.

Program padat karya yang dianggap paling berhasil oleh masyarakat ternyata tidak dilanjutkan oleh pemerintah, karena bersifat crash program. Pemerintah kemudian menggulirkan program P2KP (Program Pengentasan Kemiskinan Perkotaan) dengan membentuk Badan Keswadayaan Masyarakat di masing-masing Kelurahan. BKM ini menyusun dan melaksanakan mekanisme bantuan kepada warga miskin berupa bantuan kredit modal usaha. Warga diminta membentuk kelompok-kelompok lengkap dengan pengurus kelompok yang akan membagi kredit kepada anggotanya dan menagih serta menyetorkan kepada BKM.

Menurut warga program ini cukup baik, dalam arti banyak kelompok terbentuk dan berhasil menyalurkan bantuan kredit secara lancar. Beberapa orang merasa terentaskan dari kemiskinan. Mereka merasa 
diuntungkan karena bunga hanya $1,5 \%$ per bulan, sedangkan pelepas uang yang kadang berkedok koperasi mengenakan bunga $20 \%$ per bulan.

P2KP secara umum dianggap berhasil oleh masyarakat, tetapi secara khusus tidak mengenai sasaran karena diperuntukkan bagi orang yang sudah mempunyai usaha. Bagi warga miskin yang tidak mempunyai usaha, maka P2KP belum dapat melayani.

Pengurus P2KP juga terikat oleh aturan kredit yang sudah ditetapkan oleh pemerintah berupa petunjuk pelaksanaan (juklak) dan petunjuk teknis (juknis). Seandainya suatu kelompok gagal mengembalikan pinjaman tepat pada waktunya, maka kelompok itu tidak dapat memperoleh kredit lagi. Padahal yang tidak mengembalikan kredit hanya satu atau dua anggota saja. Hal ini banyak dikeluhkan oleh warga yang rajin dan tepat waktu mengangsurnya.

Program yang juga dianggap berhasil adalah program beras miskin (Raskin) dan Program Jaminan Kesehatan bagi warga miskin (Askeskin atau Kartu Sehat). Disebut Askeskin karena program yang bersifat nasional ini dilaksanakan oleh PT Askes yang diperuntukkan bagi warga miskin. PT Askes mengeluarkan Kartu Peserta yang harus dibawa oleh warga iniskin manakala mereka berobat ke Puskesmas dan Rumah Sakit Negeri. Kartu Peserta ini yang dikenal sebagai Kartu Sehat oleh warga masyarakat. Sedangkan beras raskin diberikan kepada mereka yang menurut pendataan Badan Pusat Statistik tergolong keluarga miskin. Setiap keluarga mendapat jatah $20 \mathrm{~kg}$ dengan membayar Rp. 1.000,-/kg. Kalau harga beras di pasaran Rp. 4.000,- maka pemer ntah memberi subsidi sebesar Rp. 3.000,-/kg dari dana subsidi kenaikan harga Bahan Bakar Minyak (BPS, 2005).

Kedua program ini cukup favorit di sebagian besar warga miskin, oleh karena bantuannya jelas berupa biaya kesehatan dan murahnya bahan pokok sehari-hari yang sangat dibutuhkan masyarakat. Menurut warga kedua program itu harus dilestarikan oleh pemerintah, siapapun yang menjadi presiden. Tetapi menurut beberapa warga program ini ticlak mendidik masyarakat, seharusnya mereka juga diminta iuran walaupun tidak sebesar perusahaan asuransi kesehatan, tetapi sifat miendidiknya nampak sehingga masyarakat terbiasa menyisinkan sebagian penghasilannya untuk biaya kesehatan.

Program yang dianggap gagal oleh masyarakat adalah programprogram pelatihan. Program ini sering kali tidak disiapkan secara baik, karena dananya turun pada akhir tahun (bulan Oktober, November dan Desember) dan segera dipertanggungjawabkan. Oleh karena itu 
pesertanyapun tidak diseleksi secara baik. Umumnya mereka yang dekat dengan sumber berita saja yang dapat mengikuti program pelatihan. Kaderkader yang sering ke kantor kelurahan adalah mereka yang cepat memperoleh informasi tentang akan adanya prgram-program pelatihan. Yang dimaksud kader adalah mereka yang aktif di lembaga PKK, RT, RW, kesehatan, sosial dan karang taruna. Karena semua informasi selalu melalui kelurahan, maka mereka yang datang pada saat ada informasi datang dari pemerintah kota akan memperoleh akses mengikuti pelatihanpelatihan itu. Pihak penyelenggarapun juga berorientasi agar proyeknya segera selesai tepat waktu dan laporan pertanggungiawabannya dapat dibuat sebaik mungkin. Baik disini dalam pengertian pelatihan selesai, jumlah peserta memenuhi syarat dan uang proyek terserap $100 \%$. Soal kelanjutannya pihak penyelenggara tidak merasa ikut bertanggung jawab. Oleh karena itu beberapa pelatihan yang disertai bantuan barang modal pada alkhirnya tidak ada hasil. Bantuan mesin jahit mereka jual dengan alasan tidak ada orang yang menjahitkan pakaian, padahal tuntutan kebutu'an pokok tidak dapat menunggu. Demikian pula dengan bantuan kompresor, alat-alat perbengkelan dan apapun yang dapat mereka jual untuk memenuhi kebutuhan sehari-hari.

\section{Aspirasi Keluarga Miskın}

Aspirasi yang mereka sampaikan baik warga miskin maupun tokohtokoh setempat antara lain:

1. Pemerintah agar melibatkan warga miskin dalam program-program pengentasan kemiskinan mulai dari perencanaan, pelaksanaan sampai pengawasannya.

2. Warga miskin agar mempunyai wadah semacam paguyuban yang dapat menampung berbagai berbagai aspirasi, usul, saran dan kritik.

3. Setiap program pengentasan kemiskinan diharapkan ada tindaklanjutnya, seperti pelatihan diikuti penampungan tenaga kerjanya atau pemasaran hasil produknya.

4. Perlu penanganan yang komprehensif, terpadu dalam koordinasi suatu badan pemerintah sehingga pengentasan kemiskinan benar-benar dapat dilihat hasilnya, terutama persamaan persepsi dalam pendataan, sehingga sasarannya tepat.

5. Perlu penanganan khusus di bidang mental spriritual dan moral warga miskin dengan melibatkan kaum ulama sehingga motivasi warga miskin tidak mudah patah dalam menghadapi tantangan yang berat ini. (GAPRI, 2004). 


\section{Penutup}

Evaluasi terhadap program pengentasan kemiskinan di Kelurahan Kricak menghasilkan pengetahuan bahwa berbagai program yang telah dilaksanakan oleh pemerintah tidak seluruhnya berhasil. Hal itu disebabkan kurangnya partisipasi masyarakat, khususnya warga miskin dalam penyusunan perencanaan program pengentasan kemiskinan. Dan ada kecenderungan untuk sekedar menghabiskan anggaran agar dianggap sukses, padahal sasarannya tidak tepat.

Diharapkan pemerintah mau mendengarkan aspirasi warga miskin agar program pengentasan kemiskinan benar-benar dapat mengurangi jumlah keluarga miskin di Kelurahan Kricak. Aspirasi warga miskin antara lain meminta dilibatkan dalam penyusunan perencanaan program, pembentukan wadah paguyuban bagi mereka, ada tindak lanjut setelah program pelatihan dalam hal penyaluran tenaga kerja dan pemasaran hasil produk, dan peranan kaum ulama untuk memperbaiki moral mental warga miskin serta membangkitkan semangat untuk dapat keluar dari predikat miskin.

\section{Daftar Pustaka}

Awan Setya Dewanta, dkk. 1995. Kemiskinan dan Kesenjangan di Indonesia. Yogyakarta: Aditya Media.

Badan Pusat Statistik. 2005. Kota Yogyakarta Dalam Angka. Yugyakarta: BPS Kota Yogyakarta.

Gerakan Anti Pemiskinan Rakyat Indonesia. 2004. Daulat Rakyat Dasar Kebijakan Anti Pemiskinan. Jakarta: GAPRI.

Gunardo R.B. 2007. Pengentasan Kemiskinan di Kelurahan Kricak Kecamatan Tegairejo Kota Yogyakarta. Yogyakarta: FISE UNY.

Harian Kompas. 2005. Orang Miskin Versi Pemerintah. Sabtı 17 Desember 2005. Jakarta: PT. Kompas Media Nusantara.

Majalah Tempo. 2006. Menjejak Sukses Grameen Bank. 19 November 2006. Jakarta: PT Temprint. 